\title{
The relationship of a teacher and a learner from different cultural backgrounds: some retrospective views of the young Romani
}

\begin{abstract}
Streszczenie: Formalna i nieformalna relacja między nauczycielem a uczniem jest istotnym aspektem, który bezpośrednio przekłada się na jakość procesu edukacyjnego. Z perspektywy inkluzji istnieje jeszcze większa potrzeba skupienia uwagi także na płaszczyźnie relacji nauczyciela i ucznia z innego kręgu kulturowego, ponieważ specyfika społeczno-kulturowa przenika do codziennych interakcji w szkole i w istotny sposób warunkuje motywację i uczenie się ucznia romskiego. Celem prezentowanych w artykule badań było wyjaśnienie istotnych aspektów relacji nauczyciel-uczeń, które mają wpływ na młodych Romów, oraz na ich postrzeganie szkoły i edukacji. Z badań wynika, że za istotne aspekty można uznać postrzeganie nauczycieli przez uczniów (koncepcje wstępne), poziom otrzymywanej pomocy i wsparcia, nierówności i dzielenie się z uczniami informacjami o ich perspektywach.
\end{abstract}

Słowa kluczowe: uczeń romski, edukacja, relacja, nauczyciel, klasa szkolna

\section{Introduction}

Ever since 1989, the society has encountered the phenomenon of exclusion of culturally and ethnically different communities, groups or individuals, which has negatively affected both the majority society and the minorities in it. After two decades of the $21^{\text {st }}$ century, the battle against social exclusion, particularly through integration of the Romani minority is the subject matter of many national and supranational strategies. The fulfilment of this challenge is to a large extent linked to the successfulness of the education of the Romani pupils.

Education of pupils from disadvantaged localities of the Romani citizens is a priority perspective of the integration process. ̌̌íčan (1997) emphasised the socialization of Romani pupils, which tremendously lags behind even today, not only in the school environment. More than twenty years ago the theses 
and a more complex viewpoint of the socialization of the Romani pupil and their education and training in primary school were clear. All the trends merged in the perspective of a systemic solution. The solutions demanded analyses of the entire situation, particularly the evaluation of external and internal factors affecting the Romani pupil. Within the framework of the ascertained facts, can be stated that a significant role is played by the closest of the pupil, the community in which they live, the narrower family environment and school. All these aspects have their specifics in the context of social exclusion, which may negatively impact the education of the Romani pupil. From the GAC project (2007) it is clear that of ten Romani pupils, most of the boys and half of the girls leave the standard Czech primary school to join special schools. This failure may be due to many issues relating to the language proficiency of the pupil (Kaleja, 2011), perception of time for duty and free time (Němec, 2010), the Romani children's preparation for school (basic mathematical ideas, etc.) and the overall support for learning among the Romani pupils with special educational needs.

The high absence rate of the Romani pupils is evaluated as a highly problematic issue and is comprehended as, so-called, hidden truancy. This type of absence is usually linked to the significance of school and education for the Romani minority. In the past, school and learning did not play an important role in the Romani community. The essential knowledge was handed down from generations to generations through oral folk tradition. Now school is mostly understood as an obligation imposed by the state.

Due to the low professional aspirations of pupils and their families and the overall low employment of the Romani (GAC, 2007), the school does not

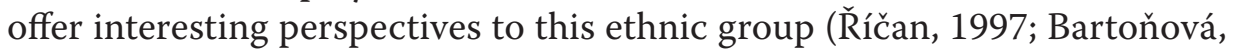
2005). Jaroslav Balvín (2004) hints that the family traditions and the educational system of school are heading for a collision of values because in the eyes of the majority of the Romani parents, there is no link between the education and economic stability or social success. Moreover, many parents do not have positive school experience (Balvín, 2004). Through the intergeneration transfer, this may be reflected in the pupil who already has a complicated situation at present.

The support for the education of the Romani pupil can be seen in the supportive texts which offer a methodology for teachers and their teaching in a diversified class (Kaleja, 2017; Balvín, 2004; 2007). Often, the strategies related to tutoring, the applied methods tailored to the teaching of classes with a pupil from a different cultural background are becoming the focus of 
attention. Co-operation with the parents of the pupil and establishing a relationship with his family seems to be highly effective. Nevertheless, some emphasis is placed on the foundation stone of the entire educational process, on the framework of the interpersonal teacher-pupil relationship in which the interaction and communication necessary for pedagogical action take place. As it is clear, the relationships in the class influence pupils' learning, particularly through motivation (Chistophel, 1990). If the pupil does not like the teacher, a situation may occur in their case consisting in avoiding the subject, tests and the teacher (Christophel and Gorham, 1995). In consequence of this, students do not need to count on motivation to learn, this reduces their affection for the learning material, the teacher and the school, and thus the probability of a failure of the pupil also increases. This fact indicates that a good teach-pupil relationship can be considered as a determinant of the quality of education and this applies two-fold in the context of multicultural educational issues. Due to this fact, the study has advanced the following research question: What are the significant aspects of the teacher-pupil relationship that influenced the young Romani and their viewpoint on school and education?

\section{Methods}

For the purposes of this study, the qualitative research approach was chosen through which it is possible to go deeper into the issue of the relationship of the teacher and pupil from a different cultural background. As we wanted to capture the aspects of the teacher-Romani pupil relationship that influenced the educator in their attitude and viewpoint on the school and education, we decided to make use of the advantages of a narrative interview with the participants, who had just completed primary education. The purpose of such an interview is to trigger narration, which provides loosely based significance (Hendl, 2008) that is strongly selective, construed and made in context (Andrews, Squire and Tamboukou, 2013). For this reason, it was our interest to follow the recommendations of Rosenthal (1995), who emphasised that narration must be on topics in their full breadth because the significances may appear on the overall background of the story, or may change in-between time frames.

The narrations were obtained from six young Romani (aged 16-21), living in an excluded locality in the Moravian Region of the Czech Republic. They were four men and two women, all of whom had completed primary school. 
Four of the participants went to vocational school, and terminated their studies within the first year.

Processing of the data obtained from the narrations was related to thematic analysis, which is one of the approaches (models) of narrative analysis. This type of analysis is concerned with the content of the text and the researcher looks for "what" the participant is saying with focus on significance (Reissman, 2008). Focus on the content was ensured by the procedure of Earthy and Cronin (2008), which recommended that the analysis should include the elements related to the following questions: "What happened?", "Who was present?", "How did the parties react to the plot?", "What is the significance of the narrated situation?". The purpose of the selected procedure was to uncover the common thematic elements in the dialogues (Reissman, 2008), which were subsequently reflected in several categories specified and interpreted in the following lines.

\section{Research results}

The analysis results are related to the five topics, which describe the teacherpupil relationship in the contexts of education in the school environment influencing the attitudes of the young Romani to school.

\section{Pre-concepts concerning teachers}

None of the narrators traditionally attended nursery school, so the relationship started being formed only upon start of compulsory school attendance, especially through the adaptation programmes for pre-school children mediated by social welfare workers. In spite of this, the comprehension of the role, significance and powers of the teacher is formed only upon the start of school attendance. Here, a fundamental role is played by the pre-concepts, which are rather the distorted ideas that interfere with the Romani pupil's perception of the teacher. The pupils from this ethnic group consider the teacher, for instance, as a dictator representing the "gadjos - red necks", who will force them into something that they and their families do not want or accept. This idea is based on the transferred experiences of the parents or other Romani pupils and may trigger negative emotions in the pupil. This may be confirmed by the contention of the narrator who said that "already due to what my brother said I had a bad notion of the teacher, and I was afraid of going to school. I thought that the teachers would beat me. So, I got prepared to 
defend myself." Nevertheless, the pre-concept concerning the teacher may be positively tuned from the beginning, and after entering school, the model of the mistress as a good-natured lady conflicts with the reality and suppresses the pupil's negative perception of the teacher particularly in situations where the teacher wants the pupil to fulfil a task and punishes them for disciplinary transgressions, or for not respecting the instructions of the teacher.

At this moment, the initial idea sharply changes alongside the attitude to school and education. The pre-concepts may also be related to the activities of the teacher and their powers. In the eyes of the Romani narrators, the teacher should be profiled as the teacher of reading, writing and counting. Emphasis on these activities of the teacher may also be caused by pre-concepts pertaining to school itself, where from the viewpoint of our participants this would be the major role of school. Due to the fact that the framework of the activities and powers of the teacher have transcended this idea, the relationship of the teacher and pupil has substantially become complicated and the pupil has rather assumed a negative attitude. "I had a different notion of teachers, the teacher should teach how to read, write and count, and for this reason I attended school, not for them to give me exercises and poor grades." The situations in which the Romani students lose their ideal teacher can be particularly emotional.

\section{The level of learning support and help}

A significant aspect of the teacher-pupil relationship is the level of perceived support and help. It seems that the Romani pupil needs to perceive the immediate presence of the teacher in class. This presence is manifested mainly in the fact that the teacher lends a helping hand at any time and hence fosters self-esteem and security in the pupil. One of the narrators stated the following: "The teacher never left me alone, something happened and he helped me with everything." Although it may suggest that this indicates a less independent Romani individual in school, the teacher's help and cooperation with the Romani pupil seems to be a major pillar of a good relationship. Pupils appreciate the accommodating attitude of the teacher and favour such a teacher. "I like the teacher a lot, I did what she said because she always helped me. I even cried when I was ill and could not go to school." In an opposite case where the teacher requires independence and the perceived level of help and support is low, the Romani pupil alienates the teacher and significance of school, which is confirmed, for instance, by the following contention: "She 
always showed us some mathematics and went away, she simply went away, so what is the purpose of such a school?"

\section{Inequality}

In most of the cases, a child from a different cultural background starts learning about the culture of the majority society upon entering school. The current school has still not gone so far as to respond in an inclusive manner to the multi-cultural diversity in class. This strongly impacts the thinking of the Romani pupils about themselves and the culture of the "gadjos", i.e. the white majority society; hey mainly see the differences in the behaviour and customs. The participants stated that they have experienced many situations of inequalities in the approach of teachers and their behaviour. "I do not know why I should try when the schoolmistress talked differently to the other gadjos and talked differently to me. For that matter, they said that she behaved differently when I was not there."

In all the narrators saw the entire problem in the inequality of obeying the rules when teachers demanded respect for rules that they did not obey themselves, for instance, "They (teachers) want us to follow the rules and do not obey them themselves". Romani pupils may be particularly sensitive to breaking the rules because they grow up in an atmosphere of certain freedom without a formal regime. Within the framework of the school environment, they thus make an effort to adapt to the school attendance conditions, and this may be a problem for them. This raises doubts in the teacher-pupil relationship concerning the authority, credibility of the teacher and the overall purpose of school rules.

Similarly, this may also occur in the perception of inequality in conduct, where the Romani acts according to the simple "action - reaction" mechanism. If the teacher raises their voice then the Romani pupil also raises their voice. Here, we can observe higher interactivity on the part of the individual from the Romani ethnic group. The Romani may be more expressive and temperamental than the individuals from the majority society. Action on one side triggers a reaction on the other side. This mechanism is naturally based on equality. Symbolically, this can be expressed by the words "if you can then I also can". In the narrated situations, statements like the following appeared: "She threw me to the ground, but when I did the same myself, I was considered as the worst pupil" or "She strongly pressed my hand, it was really painful... so I hit her with the table, not much but I pushed it against her. 
Then I was punished and she wasn't." Punishment in such cases is perceived by pupils as unjust because they subjectively see the entire conflict from the opposite side. They feel wholly innocent and perceive their own behaviour as a response triggered by the teacher. The relationship with the teacher in the context of such a situation is substantially disrupted and for this reason, the conflicting situations may recur more often.

\section{Solutions to problems and conflicts}

A gig narration topic comprised school conflicts of pupils related to the solution of situations associated with violation of school rules. The Romani ethnic group responds very well to the democratic management of conflicts. They need to know that the teacher solves the problem justly, they are capable of excusing the ignorance of the pupil in cases where rules are broken and do not write the student off and tag this student as an "unmannerly" individual. Due to the fact that the pupils perceive the "difference" and inequality, negative tagging may be a criticism of their personality and may be more sensitive than for the pupils from the majority society. The conduct of the teachers is intensively observed, in other words, the Romani individuals focus more on actions. They appreciate the moments when the teacher helps them solve a situation in a dignified manner. This is exactly what arouses confidence in them. This may be observed in the following contention: "Our class teacher showed us that things can be done differently and for this reason I had confidence in him. When he had a problem with me, he took me aside and we discussed the issue. He was not the type that immediately ran off to the headmaster and made a bigger problem of the issue."

A big role is played by the class teacher, who may be comprehended as the saviour of problematic situations, for instance "The class teacher immediately came to my rescue, he believed that I was not to blame, that I did not do it. Then it was discovered that the boys did it. He was simply like my friend." or "I can thank the class teacher because she discussed my issue with the Czech teacher and I would certainly have failed without her." In these cases, it is clear that if the teacher expresses interest in the pupil, that they take the pupil not only as a pupil, but also as a child - as a learning subject, who makes mistakes, just like an adult can also do, they bring a human touch to the whole issue, and thus increase the kindness of the pupil to the teacher, and take the relationship between them as healthy interaction. 


\section{Sharing the perspectives}

Although polemics are often held over the low aspirations of the Romani within the scope of their future; in this study, it seems that the perspectives of the further life of the Romani pupils play an important role in the teacherpupil relationship. The narrators highly positively perceived the situations in which the teachers supported or were interested in their further steps in life. "Some teachers did not want to approve my further education, but my teacher approved it for me and supported me; this influenced me quite a lot" or a another narrator said "I was glad that she herself proposed that I should take a try at becoming a cook." In the broader context, this concerns the fact that career counselling in the classrooms is traditionally for all pupils and parents.

A Romani pupil needs not always necessarily consider long-term study as a preparatory phase for a future professional career, but just like the fellow pupils from the majority society, they are also concerned with the choice of school, and the related issue of "becoming". Fears of the negative response of the teacher may arise, which shall subsequently raise doubts in the pupil concerning their own capabilities. "I wanted to go to a building school, but I did not know what the teacher would say about it, I had a lot of problems with her and that primary school was nothing much for me, but I liked other things. She told me that it was a good idea that I wanted to go to a building school, that it suited me. I gave it a try." The pupils appreciate that the teachers share their ideas of life after compulsory education with them even in the cases where the pupils do not want to continue secondary school education. "She knew that I could not cope so she never forced me to apply to another school. She always told me that I would never get lost in the world."

\section{Discussion and conclusion}

As regards the research results, it is necessary to consider three ideas more intensively. In the first place, this concerns the improvement of the quality of teacher training or work with pupils from disadvantaged localities and different cultural backgrounds. This thesis is also shared by Martin Kaleja (2014), whose study proved the low awareness of teachers concerning the problems of social disadvantage. At the same time, more emphasis should be placed on 
the aspect of relationship in education. The results of this study indicate that access to the pupil through an informal relationship substantially influences the attitude of the Romani to learning and education.

Further, it seems necessary to devote proper attention to the pre-concepts of the pupil regarding the teachers and importance of school. This thesis could be realised through a compulsory year in nursery school. The preconcepts are substantially influenced by the cultural and social background of the pupil, and it seems that they may complicate formation and development of the teacher-pupil relationship. Moreover, they may result in the demotivation of the pupil and may enhance the negative attitude to school. For this reason, some consideration is recommended concerning the pre-concepts already during work in the preparatory year of pre-school children within the framework of education in the nursery schools. Work with imagination should be based on diagnostics and the influence of pre-concepts of school and teachers. The last significant aspect of the relationship is sharing the perspectives with the pupil. Within the framework of compulsory education, it is necessary to monitor the development of the subjective perspective of pupils concerning their future life, on "who they want to be in future". The teacher's opinion is also fundamental for the pupil. The fact whether the teacher shows confidence in the pupil's abilities may to a certain extent promote or increase the prospects and aspirations of Romani pupils.

\section{Acknowledgement}

This article was supported by the project IGA/FHS/2019/001 - Teacher immediacy in the school classroom (Tomas Bata University in Zlín, Faculty of Humanities, Department of Pedagogical Sciences, Czech Republic).

\section{Bibliography}

Andrews, M., Squire, C. and Tamboukou, M. 2013. Doing Narrative Research. Thousand Oaks: Sage Publication.

Balvín, J. 2004. Výchova a vzdělávání romských žáků jako pedagogický systém. Praha: Hnutí R.

Balvín, J. 2004. Metody výuky romských žáků. Praha: Hnutí R.

Bartoňová, M. 2005. Současné trendy v edukaci dětí a žáků se speciálními vzdělávacími potrebami v České republice. Brno: Paido. 
Christophel, D.M. 1990. The relationships among teacher immediacy behaviors, student motivation and learning. Communication Education. 39 (4), pp. 323-340.

Christophel, D.M. and Gorham, J. 1995. A test-retest analysis of student motivation, teacher immediacy, and perceived sources of motivation and demotivation in college classes. Communication Education. 44, pp. 292-306.

Earthy, S. and Cronin, A. 2008. Narrative analysis. In: Gilbert, N. ed. Researching Social Life. London: Sage, pp. 420-439.

Gabal analysis \& Consulting. 2007. Závěrečná zpráva výzkumného projektu Analýza postoju a vzdělávacích potreb romských dètí a mládeže. Praha.

Hendl, J. 2008. Kvalitativní výzkum: základní teorie, metody a aplikace. Praha: Portál.

Kaleja, M. 2014. Czech socially excluded Roma pupils in the context of educational process. Educational Alternatives. 12, pp. 738-750.

Kaleja, M. 2017. Metodický text pro pedagogické pracovníky romských žáki̊ základních škol. Praha: Slovo 21.

Kaleja, M. 2011. Romové a škola versus rodiče a žáci. Ostrava: PdF Ostravské univerzity v Ostravě.

Němec, J. 2010. Edukace romských žáků v zrcadle výzkumných šetření. Brno: Masarykova univerzita.

Riessman, C.K. 2008. Narativní metody pro lidské vědy. USA: SAGE.

Rosenthal, G. 1996. Erlebte und erzahlte Lebensgeschichte. Frankfurt: Campus.

Říčan, P. 1997. Socializace romských dětí ve škole. Pedagogická orientace. 2, ss. $40-54$.

\title{
The relationship of a teacher and a learner from different cultural backgrounds: some retrospective views of the young Romani
}

\begin{abstract}
The formal and informal relationship of the teacher and pupil is a significant aspect, which is directly reflected in the quality of the educational process. Due to inclusion, there is an even greater necessity to focus attention also on the relationship plane of the teacher and pupil from a different cultural background because the socio-cultural specifics permeate into the daily interactions in the school and they substantially influence the motivation and learning of the Romani pupil. The objective of the presented study was to clarify the significant aspects of the teacher-pupil relationship that influenced the young Romani and their view-
\end{abstract}


point on school and education. It seems that the significant aspects that can be considered as pre-concepts are teachers, the degree of perceived help and support, inequality and sharing the perspectives of the pupils.

Keywords: Roma pupil, education, relationship, teacher, school classroom

Translated by Renáta Matušů 